\title{
BACTERIOPLANCTON IN DIFFERENT TIDES OF THE PEREQUÊ TIDAL CREEK, PONTAL DO SUL, PARANÁ, BRAZIL
}

\author{
Hedda Elisabeth Kolm*; Lucimar Andretta
}

Centro de Estudos do Mar da Universidade Federal do Paraná

Submitted: July 24, 2001; Returned to authors for corrections: June 12, 2002; Approved: May 08, 2003

\begin{abstract}
The influence of tidal phase on bacteria abundance in surface waters was studied in five stations along the Perequê tidal creek (Paraná State, Brazil), at spring and neap low and high tides in July 1999. The stations were located from the mouth (St.1) to the creek's head (St. 5). The following parameters were analyzed: salinity, temperature, $\mathrm{pH}$, dissolved oxygen, total carbon dioxide, seston, particulate organic matter, pluviosity, chlorophyll "a", total heterotrophic bacteria, bacterial biomass, cultivable heterotrophic aerobic halophilic and halophobic bacteria, total coliforms and Escherichia coli. The results showed that the highest values of salinity, $\mathrm{pH}$ and dissolved oxygen at stations 1 to 4 were registered during the spring high tide. The amount of total heterotrophic bacteria was directly proportional to seston and chlorophyl values at stations 2 and 3 during low tide of July 28, and at station 5 during high tide of the same day. The values of cultivable heterotrophic aerobic halophilic and halophobic bacteria, total coliforms and E. coli, were directly correlated with particulate organic matter and pluviosity. The largest of these values were registered during the neap low tide of July 6 . This period was characterized by high precipitation, which may have influenced the bacterial number variation. During the neap high tide and, sporadically, during the neap and spring low tide, the lowest values of total heterotrophic bacteria and bacterial biomass were registered. The results showed great influence of the tide on the bacteria at stations 1 to 4 , but not at station 5 .
\end{abstract}

Key words: bacteria, tide, tidal creek, Perequê, Paraná State

\section{INTRODUCTION}

Bacteria occur in all marine environments. Their importance is highest in the coastal regions due to the input of organic matter and nutrients from the continent $(10,12,25)$. In these regions, quantitative and qualitative changes in the environmental characteristics may occur and consequently the bacteria, due to an antropic influence also change (18).

In coastal regions, mainly in bays and estuaries, halophilic, halotolerant and halophobic bacteria can be found. Halotolerant bacteria are adapted to live in regions of intermediary salinities, halophilic bacteria in high salinities and halophobic bacteria, brought mainly by rivers, develop better in fresh water cultures and only survive for a limited time in the sea (25).
Few bacteriological studies have been carried out in South Brazilian estuarine waters. Abreu (1) and Abreu et al. (3) studied the microbial food web in a shallow region of the Patos Lagoon estuary, State of Rio Grande do Sul. Abreu et al. (4) working on a estuarine plume in the coastal region close to the Patos Lagoon mouth, found a decrease in bacterial number and activity (measured with ${ }^{3} \mathrm{H}$-Thymidine) at the sharp interface of estuarine and coastal water, probably due to salt stress on the bacterial community. In large scale study of the Patos Lagoon, Abreu and Odebrecht (2) concluded that there was no significant relationship between bacteria and clorophyl "a", while a stronger correlation was found between bacteria and phosphate. In the Estuarine Complex of Paranaguá, State of Paraná, Kolm and Absher (15) studied the number of saprophytes in surface waters along the Paranaguá and Antonina Bays and its

\footnotetext{
* Corresponding author. Mailing adress: Centro de Estudos do Mar, Universidade Federal do Paraná. Av. Beira Mar, s/nº Caixa Postal 50.002
} 83255-000, Pontal do Sul, PR, Brasil. Telephone: (+5541) 455-1333. E-mail: hedda@aica.cem.ufpr.br 
interrelationship with environmental factors. They concluded that a positive correlation has occurred among cultivable heterotrophic bacteria in surface waters and rainfall in the studied period and region. Kolm and Lesnau (16), studying the variation of saprophytic bacteria in two water columns, one close and another distant (approx. $5.5 \mathrm{Km}$ ) of mangrove regions, concluded that, although waters of the continental shelf influenced both regions, variations existed in regard to the aquatic ecosystems conditions. Kolm et al. $(17,18)$ published the first data about total heterotrophic bacteria, bacterial biomass and total and fecal coliforms, and their interrelationship with abiotic data at the Paranaguá and Antonina Bays, PR. Schoenenberger (26) reported the first bacteriological study at Guaraqueçaba and Laranjeiras Bays, State of Paraná.

The objective of the present research was to study the spatial and temporal variations of total heterotrophic bacteria, halophobic and halophytic saprophytes, total coliforms and Escherichia coli in surface waters along the Perequê tidal creek, in a winter month with little rainfall. Their interrelationship with biotic and abiotic data in a lunar cycle of semidiurnal tides was also evaluated.

\section{MATERIALS AND METHODS}

\section{Study area}

Perequê tidal creek (Fig. 1), approximately 2.6 km long (19), is part of the Estuarine Complex of Paranaguá, State of Paraná,

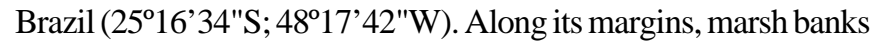
(Spartina alterniflora) and mangroves, with the predominance of Laguncularia racemosa (white mangrove) can be found. In the highest and driest areas of the tidal creek, Hibiscus tiliaceus and sand dune vegetation can be found (6).

The flow of water at Pereque tidal creek is dominated mainly by the tidal regime in the area, presenting flow in both directions, during high and low tides. Significant flow of fresh water down river only occurs during periods of intense rainfall (summer). During the remaining period, the only contribution of fresh water comes from the water table that, as it is found close to the surface of the terrain, sends variable amounts of fresh water to the tidal creeks bed. Thus, the salinity values vary with the tidal cycle (semidiurnal) and with the seasonal variations of rainfall. The waters of the tidal creek are more saline in the winter or drought period, with values up to $33 \%$, and less saline during the rainy season with values of approximately $1 \%$ o (23).

\section{Samples collection}

In July (winter) of 1999, a total of fourty superficial water samples were collected at five stations of Perequê tidal creek (Fig. 1). The collections obeyed the flow of the tide, that is, from station 1 to 5 during flow tide and from station 5 to 1 during the ebb tide. The first waters were collected on July 06 (waning moon) in the following hours: St.1- 9:34h; St.2- 10:15h; St.3- 10:37h; St.4- 10:55h; St.5- 11:10h (flow tide) and St.5-16:12h; St.4-16:30h; St.3-16:48h; St.2-17:06h; St.1-17:29h (ebb tide). The second water collection was made on July 13 (new moon) in the following hours: St.5-09:50h; St.4- 10:05h; St.3-10:24h; St.210:43h; St.1-11:05h (ebb tide) and St.1-16:09h; St.2-16:25h; St.316:45h; St.4-17:00h; St.5-17:14h (flow tide). On July 20 (waxing moon) the waters were sampled at: St.1-08:32h; St.2-08:51h; St.309:10h; St.4-09:25h; St.5-09:39h (flow tide) and St.5-12:55h St.413:08h; St.3-13:30h; St.2-13:54h; St.1-14:20h. (ebb tide). The fourth collection (full moon) was made on July 28 in the following hours: St.5-09:30h; St.4-09:47h; St.3-10:02h; St.210:17h; St.1-10:38h. (ebb tide) and St.1-15:13h; St.2-15:30h; St.315:47h; St.4-16:00h; St.5-16:14h (flow tide).

The following abiotic parameters were analyzed in all water samples: A) water temperature $\left(\mathrm{T}^{\circ} \mathrm{C}\right)$ with a standard thermometer, B) salinity with an refractometer (ATAGO S/Mill, Japan), C) pH with a portable digital $\mathrm{pHmeter}$ (Digimed), D) dissolved oxygen using the Winkler technique (11), E) total carbon dioxide using the Carmouze method of ionic interactions (8), F) seston using the GF/F filter method (28) and G) particulate organic matter with the ignition method (28). Data on pluviosity was obtained from the Marine Physics Laboratory, Marine Study Center, Federal University of Paraná. For analysis purposes, the rainfall values of six days preceeding each collection were added to the values of the collection day and the different tides were coded and ordered as: 1 - empty; 2 - low; 3 - high and 4 - full.

The following biotic parameters were analyzed: A) total heterotrophic bacteria by epifluorescence microscopy counts, using the fluorochrome acridine orange (24), B) bacterial biomass by quantification of the biovolume, according to Bjørnsen and Kuparinen (5), C) cultivable heterotrophic aerobic halophobic and halophilic bacteria using the Zobell 2216E culture medium,

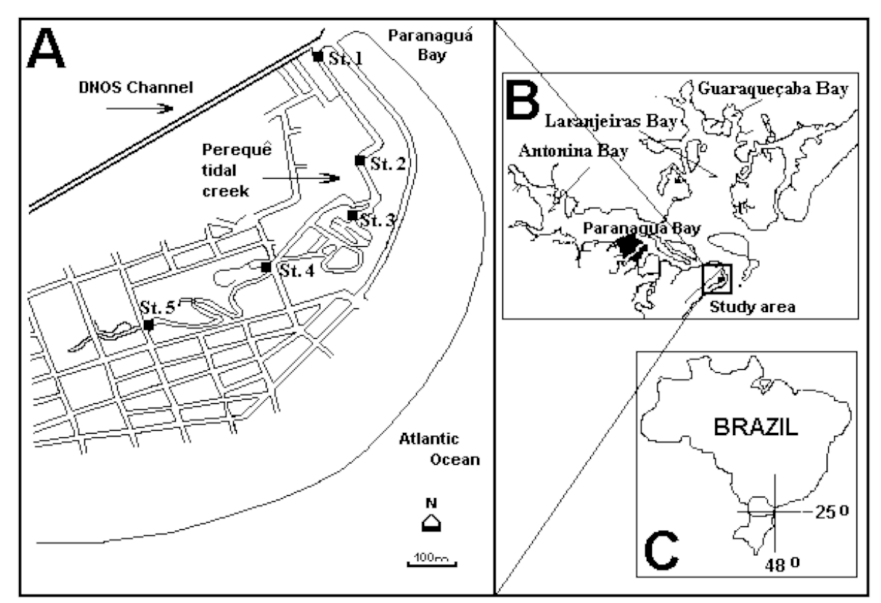

Figure 1. Map of the studied area. A) Perequê tidal creek; B) Estuarine Complex of Paranaguá showing the studied area and C) Map of Brazil showing the estuarine complex. 
following the methodology described by Kolm and Corrêa (14), D) total coliforms and Escherichia coli by the method of the Most Probable Number (MPN) using Colilert (Idexx Laboratories, Inc.) (27) and E) total chlorophyl by the fluorimetric method, as described by Strickland and Parsons (28).

The biotic and abiotic variations on the different collection dates, at high and low tides and at the sampling stations were compared using ANOVA. The results of the biotic data were presented, when significant, in the form of graphs with the respective values of $F$, degrees of freedom and significance (p).

The values of " $F$ " and "p" of the abiotic and, when not significant, of the biotic data, were inserted in the text. For identification of the temporal and spatial distribution, the data were centered, reduced and analyzed as a Principal Component Analysis (PCA), (7,20).

\section{RESULTS}

Water temperature showed a significant variation throughout the sampling period $(\mathrm{F}(7.32)=24.49 ; \mathrm{p}<0.0000)$ and not among stations. Significant differences were not observed among water temperature at different tidal heights $(\mathrm{F}(1.38)=2.87 ; \mathrm{p}<0.0982)$ and at the sampled stations $(\mathrm{F}(4.35)=0.80 ; \mathrm{p}<0.5333)$. The highest registered water temperature was $24.0^{\circ} \mathrm{C}$, at station 5 during the low tide of July 20 , and the lowest was $16.3^{\circ} \mathrm{C}$ at station 1 during the high tide of July 06.

The greatest salinity ( $32 \%$ ) was registered in the high tide of July 28 at stations 1, 2 and 3. The lowest value was of $\mathrm{H}$ " $0 \%$ at station 5, in the two (high and low) tides of July 20. The differences between the salinity values at the different collection dates $(\mathrm{F}(7.32)=9.58 ; \mathrm{p}<0.0000)$ of the different tides $(\mathrm{F}(1.38)=$ 9.78; $\mathrm{p}<0.0034)$ and sampled stations $(\mathrm{F}(4.35)=2.66 ; \mathrm{p}<0.0489)$ were statistically significant.

The highest $\mathrm{pH}$ (7.94) was observed on the July 28 , during high tide at station 1 and the lowest (6.33) during low tide of July 13 at the same station. The variation in $\mathrm{pH}$ during the spring high tide was significantly higher than during the spring low tide and neap tides $(\mathrm{F}(7.32)=15.71 ; \mathrm{p}<0.000)$. With regard to tide variations (high tide and low tide) and collection stations, the variations were not significant $(\mathrm{F}(1.38)=3.92 ; \mathrm{p}<0.0549)$ and $(\mathrm{F}(4.35)=0.45 ; \mathrm{p}<0.7709$ respectively $)$.

During the low tide of the July 13 the highest percentage of dissolved oxygen $(108.43 \%)$ and the lowest $(21.86 \%)$ were observed at stations 2 and 5, respectively. There was a statistically significant variation in the percentage of dissolved oxygen, both throughout the collection dates $(\mathrm{F}(7.32)=5.16$; $\mathrm{p}$ $<0.0005)$, the tide variation $(\mathrm{F}(1.38)=13.78 ; \mathrm{p}<0.0007)$, and among the studied stations $(\mathrm{F}(4.35)=3.51 ; \mathrm{p}<0.0164)$.

The highest percentage of total $\mathrm{CO}_{2}$ in the water occurred at station $5(7.118 \%)$ during the high tide of July 06 and the lowest at station $1(149.8 \%)$ during the high tide of the July 13 . The total carbon dioxide in the water varied significantly throughout the collection dates $(\mathrm{F}(7.32)=4.21 ; \mathrm{p}<0.0022)$, among the tide heights $(\mathrm{F}(1.38)=4.98 ; \mathrm{p}<0.0316)$ and among the sampled stations $(\mathrm{F}(4.35)=6.56$; $\mathrm{p}<0.0005)$.

The highest seston value $\left(9.23 \mathrm{mg} . \mathrm{l}^{-1}\right)$ was registered at station 1 during the low tide of the July 06 . The smallest amount (2.42 mg..$^{-1}$ ) was registered at the same station, during the high tide of July 20. The comparison of the seston values showed a significant variation with regard to the collection dates $(\mathrm{F}(7.32)$ $=4.01 ; \mathrm{p}<0.0030)$ but the variation with regard to the tide heights $(\mathrm{F}(1.38)=0.38 ; \mathrm{p}<0.5418)$ and collection stations $(\mathrm{F}(4.35)=$ $0.63 ; \mathrm{p}<0.6465)$ were not significant.

The highest value of POM was observed at station 1 (8.275 $\left.\mathrm{mg} \cdot \mathrm{L}^{-1}\right)$ during the low tide of July 06 and the lowest value (1.13 $\mathrm{mg} \cdot \mathrm{L}^{-1}$ ) at station 2 during the high tide of the same day. The amount of POM in the high tide was significantly lower than in the low tide $(\mathrm{F}(1.38)=10.93 ; \mathrm{p}<0.0021)$. There was also significant variation with regard to the collection dates $(\mathrm{F}(7.32)$ $=2.65 ; \mathrm{p}<0.0281)$ and sampled stations $(\mathrm{F}(4.35)=4.38 ; \mathrm{p}<0.0057)$.

The largest rainfall values occurred between June 30 and July $06(297.0 \mathrm{~mm})$ and the smallest ones $(12.7 \mathrm{~mm})$ in the last period of samplecollection (Fig. 2).

The highest value for total chlorophyll was observed at station 5 during the high tide of July $20\left(27.733 \mu \mathrm{g} . \mathrm{L}^{-1}\right)$ and the smallest at station 1 during the low tide of July $13\left(1.220 \mu \mathrm{g} . \mathrm{L}^{-1}\right)$. There was no statistically significant variation between the values of total chlorophyll and collection dates $(\mathrm{F}(7.32)=1.30$; $\mathrm{p}<0.2803)$, tides $(\mathrm{F}(1.38)=0.10 ; \mathrm{p}<0.7595)$ and sampled stations $(F(4.35)=1.18 ; \mathrm{p}<0.3357)$

The highest value of total heterotrophic bacteria $(\mathrm{TH})$ was observed at station 2, during the low tide of July 06 , with $3.1 \mathrm{x}$ $10^{6}$ cells. $\mathrm{mL}^{-1}$ and the lowest at station 5 during the high tide of July 20, with $3.1 \times 10^{5}$ cells. $\mathrm{mL}^{-1}$. The variation of TH was not significant with the variation of the tides $(\mathrm{F}(1.38)=0.18 ; \mathrm{p}$ $<0.6698)$ and along the studied stations $(\mathrm{F}(4.35)=0.80 ; \mathrm{p}$ $<0.5350$ ), but was significant on the different collection dates $(F(7.32)=4.37 ; p<0.0017)$, as can be seen in Fig. 3A.

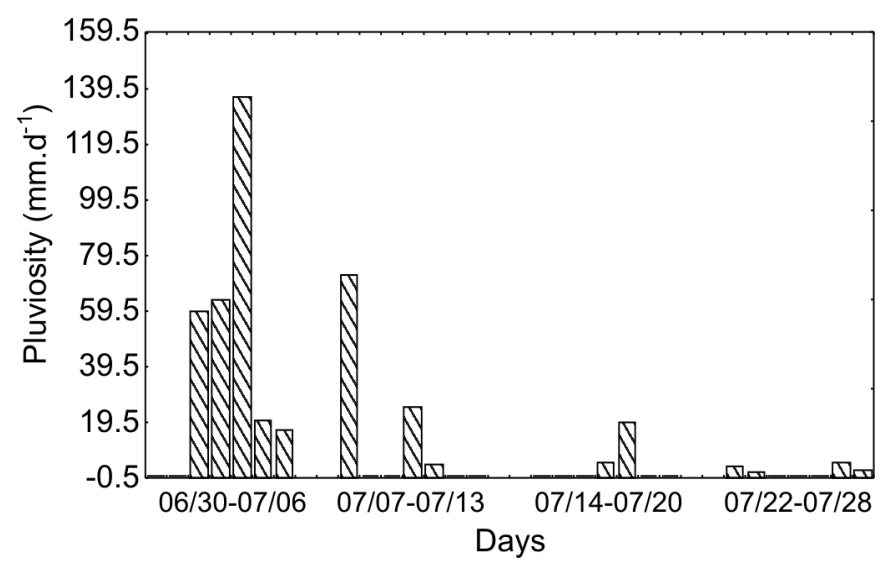

Figure 2. Rainfall during the studied period. 

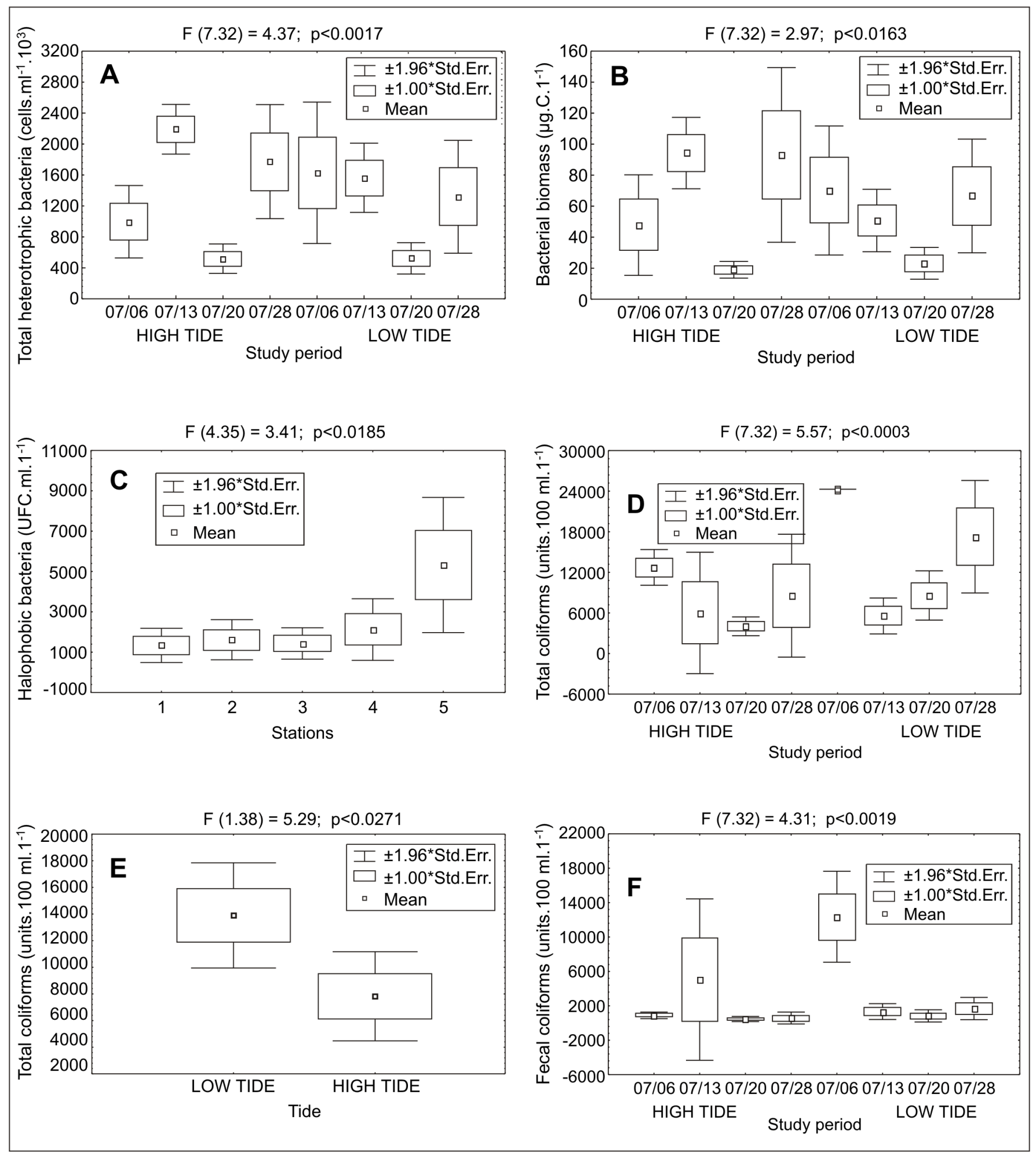

Figure 3. Graphic representation of the following analyses of variance: A) Total heterotrophic bacteria throughout the studied period; B) bacterial biomass throughout the studied period; C) cultivable heterotrophic halophobic bacteria along the collection stations; D) total coliforms throughout the studied period; E) total coliforms with regard to the tide and F) $E$. coli throughout the studied period. 
The maximum value of bacterial biomass $\left(186.99 \mu \mathrm{g} \mathrm{C.L} \mathrm{L}^{-1}\right)$ was observed during the high tide of July 28 and the minimum value $\left(1.48 \mu \mathrm{g} \mathrm{C} . \mathrm{L}^{-1}\right)$ in the low tide of July 20 , both at station 5 . There was a significant variation of the bacterial biomass throughout the studied period $(\mathrm{F}(7.32)=2.97 ; \mathrm{p}<0.0163)$ (Fig. $3 \mathrm{~B})$ and the variation was not significant among the tide variations $(\mathrm{F}(1.38)=0.63 ; \mathrm{p}<0.4307)$ and collection stations $(\mathrm{F}(4.35)=0.49 ; \mathrm{p}<0.7400)$.

The highest value of cultivable heterotrophic halophobic bacteria $\left(1.6 \times 10^{4} \mathrm{UFC}^{\mathrm{mL}} .^{-1}\right)$ was registered at station 5 during the high tide of July 13 and the lowest value $\left(1.0 \times 10^{2}\right.$ UFC. $\left.\mathrm{mL}^{-1}\right)$ on the same day and in the same tide, at station 1 . The halophobic frequencies were significantly different at the sampled stations $(\mathrm{F}(7.32)=1.24 ; \mathrm{p}<0.3038)($ Fig. 3C) and not significant with regard to the tide $(\mathrm{F}(1.38)=0.08 ; \mathrm{p}<0.7779)$ and to the collection stations $(\mathrm{F}(4.35)=3.41 ; \mathrm{p}<0.0185)$.

The highest values of cultivable heterotrophic halophilic bacteria were found at station 5 during the low tide of July 20 , and the lowest values at station 1 during the high tide of July 13. The variations with regard to the studied period $(\mathrm{F}(7.32)=2.12 ; \mathrm{p}$ $<0.0694)$, to the tides $(\mathrm{F}(1.38)=2.58 ; \mathrm{p}<0.1168)$ and to the collection stations $(F(4.35)=1.27 ; p<0.3019)$ were not significant.

During the low tide of July 06 the highest values of total coliforms were registered (> $\left.2.4 \times 10^{4} \mathrm{MPN} .100 \mathrm{~mL}^{-1}\right)$ at all stations. The same occurred at station 5 during the high tides of July 13 and July 28, and at stations 2, 3 and 4, during the low tide of the last day of collection. The smallest value was of 3.8 $\mathrm{x} 10^{2}$ MPN. $100 \mathrm{~mL}^{-1}$ at station 1 during the high tide of July 13 . The variation of the total coliformes was significant throughout the studied period $(\mathrm{F}(7.32)=5.57 ; \mathrm{p}<0.0003)$ (Fig. 3D) and among the tides $(\mathrm{F}(1.38)=5.29 ; \mathrm{p}<0.0271)(\mathrm{Fig} .3 \mathrm{E})$ and not significant $(\mathrm{F}(4.35)=0.35 ; \mathrm{p}<0.8389)$ at the sampled stations.

During the high tide of July 13 the largest value of $E$. coli was registered $\left(>2.4 \times 10^{4} \mathrm{NMP} .100 \mathrm{~mL}^{-1}\right)$ at station 5 . The smallest value was of 10 MPN.100 mL $\mathrm{m}^{-1}$ registered during the high tide of July 13 at station 1 . The variation of the E. coli was significant throughout the studied period $(\mathrm{F}(7.32)=4.31 ; \mathrm{p}$ $<0.0019)$ (Fig. 3F). Among the tide variations $(\mathrm{F}(1.38)=1.74 ; \mathrm{p}$ $<0.1947)$ and stations $(\mathrm{F}(4.35)=0.35 ; \mathrm{p}<0.8421)$ the variations were not significant.

Fig. 4 shows the Principal Component Analysis (PCA). The first component accounted for $30.41 \%$ of the variation and showed positive correlation with $\mathrm{pH}$, salinity, dissolved oxygen and tide during spring high tide and negative correlation with neap low tides of stations 1, 2, 3 and 4 . The same component showed, at the same stations, a negative correlation with the total carbon dioxide, rainfall, heterotrophic aerobic halophilic and halophobic bacteria and total and $E$. coli in spring high tide and a positive correlation with spring and neap low tides.

The second component accounted for $19.23 \%$ of the variation and showed a negative correlation with seston, total heterotrophic bacteria, bacterial biomass and, on a smaller scale,

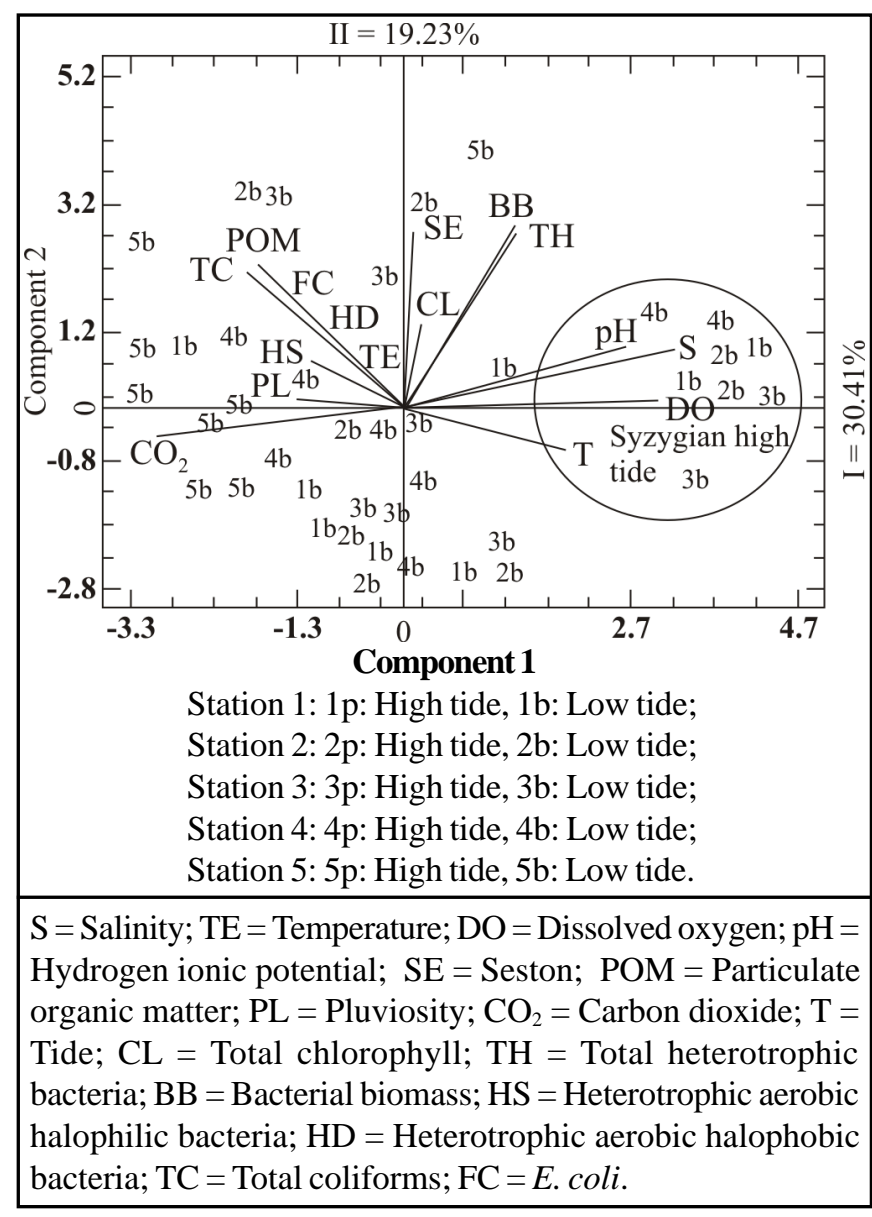

Figure 4. Distribution of the sampled stations, and of the biotic and abiotic values of the studied period, in the space of the main components.

with chlorophyll in neap high tide of stations 1 to 4 . With regard to station 5, no variation could be seen between spring and neap high tide. Except for the spring high tide of July 28, positive correlations of the waters of this station could be verified with carbon dioxide, rainfall, heterotrophic aerobic halophilic and halophobic bacteria and with the total coliforms and E. coli and negative correlations with $\mathrm{pH}$, salinity, dissolved oxygen and tide. In the spring high tide of July 28 , there was a positive correlation with the seston, the total heterotrophic bacteria, the bacterial biomass and, on a smaller scale with the chlorophyll. The temperature values were similar at all the stations and they did not influence the analysis.

\section{DISCUSSION}

Continental shelf waters are more saline, more alkaline and poorer in nutrients than those of the estuaries. As Perequê tidal creek is located close to the entrance of the Paranaguá 
Estuarine Complex, it is influenced directly, during the high tide, by the continental shelf waters. During the low tides, it drains water from the water table, rainfall and of domestic effluents. This influence is clearly seen by the high salinity, $\mathrm{pH}$ and dissolved oxygen values observed in the sampled stations closest to the outlet of Perequê tidal creek mainly in spring tides. The results show that station 5, located in the more internal area of the tidal creek, on the contrary, is less affected by the tides. This fact may be linked to the recent construction of a bike lane, with movement of sand and consequent silting up of this area.

The coast of Paraná is characterized by considerable temperature and rainfall variations between winter and summer. Maak (21) characterized the environment as being transitional tropical. Moreover, all the rainfall periods are caused by cold fronts coming from the south that move in a northward direction, provoking decrease in air temperatures and, consequently, in surface water temperatures of the region. During the studied period the highest temperature values, at all the sampled stations, were registered on July 20 (neap tide), with a maximum at station 5 , during the low tide. Considering that in the neap tide the range is small, with little change of water, and that on July 20 the weather was fair, with few clouds, and sampling at low tide was carried out around midday, we may conclude that the high temperatures observed were due to interrelationship of these factors. On the other hand the PCA showed that the temperature variation did not influence the bacterial variation throughout July, 1999.

Seston is composed by three categories of particles: mineral, transported from the continent to the water; detritus, composed of organic and inorganic particles and plankton (bacterioplankton, phytoplankton and zooplankton) (9). Rheinheimer (25) described its importance for bacterial development mainly in waters poor in nutrients. In the present study a positive correlation was verified among seston, chlorophyll, total heterotrophic bacteria and bacterial biomass at station 5, during the spring tide of July 28 and at stations 2 and 3, in low tide of the same day. In the other sampling stations and studied periods the correlation was negative or there was no correlation. According to Mantovani and Novo (22) the dissolved organic matter (DOM) can interact with the algae and bacteria, as a source of energy or organic carbon. Therefore, Kolm and Lesnau (16) supposed that in areas rich in nutrients there is free bacterial life feeding on the dissolved organic matter (DOM). As Perequê tidal creek is very rich in DOM from the adjacent mangroves, mainly during the low tides, it is likely that the total heterotrophic bacteria have a free life in this area and feed DOM.

The cultivable heterotrophic halophilic and halophobic bacteria and the total coliforms and E. coli, contradictorily, presented high positive correlation with the particulate organic matter (POM) at all stations during the low tide of July 06 (neap tide) and at station 5 during the low tide of July 20 (neap tide). The period that preceded July 06 was characterized by a cold front with high rainfall. It is likely that the heavy rains provoked the transport of POM from nearby regions to the bed of the tidal creek. The high values found in the water collected at station 5 on July 20, were punctual and mainly related to the small influence of the neap tide, typical of this station.

Kolm and Absher (15) found a correlation between the cultivable heterotrophic aerobic bacteria and high rainfall in surface waters of the Bays of Paranaguá and Antonina. Similar results could be observed in waters of Perequê tidal creek, with regard to the cultivable heterotrophic aerobic bacteria, but not with the total heterotrophic bacteria. These results confirm the description of Hoppe (13) that cultivable heterotrophic aerobic bacteria reply more quickly to environmental variations and organic pollution than the total heterotrophic bacteria.

Although the objective of the analyses was not to establish patterns for swimming waters, we observed that Escherichia coli values exceeded the maximum allowed by the Resolution 274, Article 3 of CONAMA (Conselho Nacional do Meio Ambiente) (2000) in the first neap low tide at all the sampled stations. Values above those permitted for the area were also registered at station 4, during the second neap low tide, and at stations 2, 3 and 4 in the spring low tides. In the first neap high tide (July 06) the values of stations 4 and 5 were also above the maximum permitted. In the second neap high tide the values of $E$. coli from the stations 2, 3 and 5 were below the maximum value allowed by law. In the spring high tide only the values of station 5 were above the maximum permitted. These results give evidence that a direct relationship probably exists between the tide and the amount of $E$. coli in the study area. The high values of $E$. coli registered at all stations in the low tide of July 06 may be directly or indirectly related with the rainfall.

In the same way that the sampled stations are inappropriate for bathing purposes they are also inappropriate for natural or intensive cultivation of marine foods "in natura", as described in the $20^{\text {th }}$ Resolution, Article 8 of CONAMA (1986).

These results allow us to conclude that it would be unwise to cultivate and/or consume organisms from Perequê tidal creek, mainly, with reference to station 2, frequently used for subsistence fishing. Bathing and fishing should be avoided along the whole Perequê tidal creek during or after periods of intense rainfall and at stations 2, 3 and 4 during the neap low tides.

Moreover, the results showed that in the period and in the studied area, heterotrophic aerobic bacteria and total and $E$. coli values were influenced by the spring tide, mainly after periods of intense rainfall. The neap tides influenced the total heterotrophic bacteria and the bacterial biomass. 


\section{RESUMO}

\section{Bacterioplâncton em diferentes marés da gamboa do Perequê, Pontal do Sul, Paraná, Brasil}

Com o objetivo de verificar a influência da maré sobre as bactérias foram realizadas coletas de águas superficiais em cinco pontos desde a desembocadura da gamboa (Est. 1) até o seu final (Est. 5) ao longo da Gamboa do Perequê (Estado do Paraná, Brasil), durante as preamares e baixa-mares de sizígia e quadratura em julho de 1999. Foram avaliados os seguintes parâmetros: salinidade, temperatura, $\mathrm{pH}$, oxigênio dissolvido, gás carbônico, seston, matéria orgânica particulada, pluviosidade, clorofila, bactérias heterotróficas totais, biomassa bacteriana, heterotróficas aeróbicas cultiváveis halófilas e halófobas, coliformes totais e Escherichia coli. Os resultados mostraram que os valores mais altos de salinidade, $\mathrm{pH}$ e oxigênio dissolvido nas estações de 1 a 4 foram registrados durante as preamares de sizígia. As quantidades de heterotróficas totais foram diretamente proporcionais aos valores de seston e clorofila nas estações $2 \mathrm{e}$ 3 durante a baixa-mar de 28 de julho, e na estação 5 durante a preamar do mesmo dia. Os valores de bactérias heterotróficas aeróbicas halófilas, de halófobas e de coliformes totais e $E$. coli apresentaram correlação direta com a matéria orgânica particulada e a pluviosidade. Os maiores destes valores foram registrados durante a baixa-mar de quadratura do dia 06 de Julho. Este período foi caracterizado por altas pluviosidades, que podem ter influenciado a variação bacteriana. Durante a preamar de quadratura e, esporadicamente, durante a baixa-mar de quadratura e sizígia, foram registrados os menores valores de bactérias heterotróficas totais e de biomassa bacteriana. Os resultados mostraram grande influência da maré sobre as bactérias das estações 1 a 4, mas não sobre a estação 5 .

Palavras chave: bactérias, maré, gamboa, Perequê, Estado do Paraná

\section{REFERENCES}

1. Abreu, P.C. Phytoplankton produktion and the microbial food web of the Patos Laggon estuary, southern Brazil. 1992, 100p. (Ph.D. Thesis. Universität Bremen, Fed. Republic of Germany).

2. Abreu, P.C.; Odebrecht C. Space and time variability of bacteria in the Patos Lagoon - Southern Brazil $\left(32^{\circ} S-52^{\circ} \mathrm{W}\right) .7^{\text {th }}$ International Symposium of Microbial Ecology. Santos, 1995, p.58.

3. Abreu, P.C.; Biddanda, B.; Odebrecht, C. Bacterial dynamics of the Patos Lagoon estuary, southern Brazil $\left(32^{\circ} \mathrm{S}, 52^{\circ} \mathrm{W}\right)$; relationship with phytoplankton production and suspended material. Estuar. Coast. Shelf Sci., 35: 621-635, 1992.

4. Abreu, P.C.; Granéli, H.W.; Odebrecht, C. Produção fitoplanctônica e bacteriana na região da pluma estuarina da Lagoa dos Patos - RS, Brasil., Atlântica, 17: 35-52, 1995.

5. Bjørnsen, P.K.; Kuparinen, J. Determination of bacterioplankton biomass, net production and growth efficiency in the Southern Ocean. Mar. Ecol. Prog. Ser. 71: 185-194, 1991.

6. Blankensteyn, A. Estrutura e análise experimental do funcionamento das associações da macrofauna bêntica do manguezal e marisma da Gamboa do Perequê, Pontal do Sul, PR. Curitiba, 1994, 169p. (Ph.D. Thesis. Departamento de Zoologia, UFPR).

7. Bouroche, J.M.; Saporta, G. Análise de dados. Zahar Editores. Rio de Janeiro, 1982, 116p.

8. Camouze, J.P. O Metabolismo dos Ecossistemas Aquáticos: fundamentos teóricos, métodos de estudo e análises químicas. Edgard Blücher (Ed.): FAPESP. São Paulo. 1994, 253p.

9. Dietrich, G.; Kalle, K.; Krauss, W. and Siedler, G. Allgemeine Meereskunde - eine Einführung in die Ozeanographie. Gebrüder Bornträger, 3. Aufl., Berlin, Stuttgart, 1975, 593p.

10. Gocke, K. Untersuchungen über die heterotrophe Aktivität in der zentralen Ostsee. Mar. Biol. 40: 87-94, 1977.

11. Grasshoff, K., Ehrhardt, M. and Kremling. Methods of Seawater Analysis. Verlag Chemie. Weinheim, 1983, 419p.

12. Gunkel, W. Einwirkungen des kalten Winters 1962/63 auf die Bakterienpopulationenen vor Helgoland. Helgoländer wiss. Meeresunters., 10: 246-256. 1964.

13. Hoppe, H.G. Degradation in Seawater. In: Rehm, H.-J.; Reed, G. (eds). Biotechnology. VCH Verlagsgesellschaft Weinheim, 1986, p.453-474.

14. Kolm, H.E.; Corrêa, M.F.M. Distribuição espacial e variabilidade temporal de bactérias saprófitas na praia arenosa de Pontal do Sul, Paraná. Arq. Biol. Tecnol. 37(2): 391-402, 1994.

15. Kolm, H.E.; Absher, T.M. Spatial and temporal variability of saprophytic bacteria in the surface waters of Paranaguá and Antonina Bays, Paraná, Brazil. Hydrobiologia. 308: 197-206, 1995.

16. Kolm, H.E., Lesnau, N.M. Variação espacial e temporal de bactérias saprófitas na coluna d'água da Baía de Paranaguá, Paraná, Brasil. Arq. Biol. Tecnol. 40(2): 383-395, 1997.

17. Kolm, H.E.; Schoenenberger, M.F.B.; Piemont, M.R.; Souza, P.S.A.; Schnell E Scühl, G; Mucciatto, M.B.; Mazzuco, R. Variação espacial de bactérias em águas superficiais das Baías de Paranaguá e Antonina, Paraná, Brasil. VII Congresso Latino-americano sobre Ciências do Mar, Santos. Resumo expandido. 1997, p.54-56.

18. Kolm, H.E.; Schoenenberger, M.F.B.; Piemont, M.R.; Souza, P.S.A.; Schnell E Scühl, G; Mucciatto, M.B.; Mazzuco, R. Spatial Variation of Bacteria in Surface Waters of Paranaguá and Antonina Bays, Paraná, Brazil. Braz. Arch. Biol. Technol. 45(1): 27-34, 2002.

19. Lana, P. da C., Almeida, M.V.O., Freitas, C.A.F., Couto, E. da C.G., Conti, L.M.P., Gonzalez-Peronti, A.L., Gilles, A.G., Lopes, M.J. de S., Silva, M.H.C. da.; Pedroso, L.A. Estrutura espacial de estruturas macrobênticas sublitorais da Gamboa Perequê (Pontal do Sul, Paraná.) Nerítica., 4(1/2): 119-136, 1989.

20. Legendre, L.; Legendre, P. Numerical Ecology. Elsevier Scientific Publ. Company. Amsterdam-Oxford-New York. 1983, 217p.

21. Maak, R. Geografia física do Estado do Paraná. 2 ed. Rio de Janeiro J. Olympio/ Curitiba, Secretaria da Cultura e Esporte do Estado do Paraná, 450p, 1981.

22. Mantovani, J.E.; Novo, E.M.L.M. Comportamento Espectral da Matéria Orgânica Dissolvida. Simpósio Brasileiro de Sensoriamento Remoto. Salvador, 1996.

23. Marone, E.; de Camargo, R. A maré do Rio Perequê, PR. características e tempos de inundação. III Simpósio de Ecossistemas da Costa Brasileira. Serra Negra, 1994.

24. Parsons, T.R.; Maita Y.; Lalli, C.M. Direct Counting of Bacteria by Fluorescence Microscopy. In: A Manual of Chemical and Biological Methods for Seawater Analysis. Pergamon Press, 1984, 173p.

25. Rheinheimer, G. Microbiologia de las aguas. Edit. Acribia S.A Zaragoza (Espanha), 1985, 299p.

26. Schoenenberger, M.F. Variação espacial e temporal de bactérias em águas de superfície das baías das Laranjeiras e Guaraqueçaba, Paraná, Brasil. Curitiba, 1998, 58p. (Monografia de Bacharelado. Universidade Federal do Paraná).

27. Standard Methods for the Examination of Water and Wastewater. American Public Health Association. 19 ${ }^{\text {th }}$. Edition. 1995.

28. Strickland, J.D.; Parsons, T.R. A practical handbook of sea water analysis. Bull. Fish. Res. Bd Can., 167: 1-311, 1968. 